\title{
LEGAL PROTECTION FOR THE LOSS OF THE PASSENGER OF ONLINE TRANSPORTATION
}

\author{
Pujiyono; Umi Khaerah Pati \\ Faculty of Law, Universitas Sebelas Maret \\ E-mail: pujifhuns@staff.uns.ac.id; umi_khaerah@staff.uns.ac.id
}

\begin{abstract}
Online transportation shall provide a security, comfort and safety guarantee for service users, however it is not performed in the application. Service users still have not guaranteed their rights as consumers. In the case the consumer suffers a loss, it is remain undetermined how compensation may be granted, therefore it demands an equal legal protection. Facing this condition, Law Number 8 of 1999 on The Consumer Protection has not yet stipulated slear provision regarding this matter, likewise the online transportation service users and service providers are only bound in limited aspects. The research method of this reasearch is normative legal research only focusing on the issues raised, discussed and elaborated with applying the rules or norms in positive law, using Statutory Approaches and Conceptual Approaches, with primary and secondary legal materials. The data collection technique used is literature study. The analysis technique used is the deductive method. The results showed that there was an legal relationship between service users and online transportation service providers. Consumers have the right to get protection in the form of responsibility for information, legal responsibility for services provided and responsibility for security and comfort. However, for the losses suffered, legal protection for losses incurred by passengers in online transportation mode is still poor due to lack of regulations and the undetermined standard regulations specifically in regulating online transportation modes.
\end{abstract}

Keywords: Legal Protection; Passenger Losses; Online Transportation Mode.

\section{INTRODUCTION}

The rapid development of digital industry is motivated by internet connectivity on every object, especially in industrial machines which no longer can be avoided. This digital industry is supported by culture of Indonesian people which is based on the Ministry of Communication and Information data in 2017, the citizen has been very actively interacting in online media (Qur'ani Dewi Kusumawardani, 2019: 12). E-commerce seems to be an integrated part of the lifestyle of the Indonesian people nowoday. E-commerce has the main potential in terms of transactions effectiveness which provide profit for both buyers and sellers. That is because (P. Ashokkumar, 2018: 73):

\begin{tabular}{l|ll}
\hline 220 & Yustisia Volume 8 Number 2 (May-August 2019) Legal Protection For The Loss Of ...
\end{tabular}

(C)2019; This is an Open Acces Research distributed under the term of the Creative Commons Attribution Licencee (https://Creativecommons.org/licences/by/4.0), which permits unrestricted use, distribution, and reproduction in any medium, provided the original works is properly cited. 
1. Availability of goods and services for 24 hours a day without being closed.

2. Instant updates of catalogs and prices at any time thereby saving paper and printing costs.

3. Broad visibility: Small companies can now advertise globally with minimal costs.

4. Creating the virtual community as an ideal target market to increase sales.

5. Interesting choices for people with disabilities.

Online business is also growing rapidly, one of which is online transportation. This business is the development of e-commerce in the field of land transportation with its transportation transactions using electronic media. There are many choices of online transportation mode such as Go-Jek, Grab, Anterin, Transjek, Wheel Line, Bangjek, Blue-Jek, Ojek Syar'i, Ngantor, and others. Among those online transportation service providers, only 2 (two) of them are popular, that are GoJek and Grab. The growth of the online transportation business is followed by the increasing public interest, which showed by the continued increase of application downloaders number. Massive news which perform the story of online transportation driver whose helped to make better living gives hope to the others (Kukuh Tejomurti, 2018: 462), which motivate sigificant number of peoples also register to join working in the field as well.

The appearnace of online transportation companies is not without problems. At the beginning, it has raised conflict with conventional transportation which became the first obstacle. The development of online transportation mode has led to a deceasing number of the public and conventional transportation income. Protests carried out by conventional transportation drivers, gave concequence to ban online-based transportation operation for online transportation companies through the Decree of the Minister of Transportation Number UM.302/1/21/Phb/2015 because they were considered not in accordance with Law Number 22 of 2009 on The Road Traffic and Transportation. However, Law Number 22 of 2009 does not clearly stipulate that motorbikes are public motor vehicles, but there is also no prohibition in the Law which mention any use of motorbikes as public motor vehicles. In Article 137 paragraph (2), "Passenger trasnportation using the motorized Vehicle shall be in terms of Motor Cycle, Passenger Car or bus." In Government Regulation Number 74 of 2014 on The Road Transportation is also not clearly stated the use of motorbikes as general vehicles to transport people. Article 10 paragraph (4) of Government Regulation Number 74 of 2014 on The Road Transportation only explains the technical aspects of motorbikes as transporting goods. Therefore, there are no rules that clearly regulate the existence of transportation, especially in the online-based which considered to violate the regulation of public transportation. Later, the Ministerial Decree was revoked 
because the President stated that transportation tools based on online applications were still needed by the people (Endang Wahyusetyawati, 2017: 4). Other problems arise include, the legality of online transportation mode, especially motorbikes that are used as public transportation, the poor legal protection for passengers because they are bound to the agreed standard agreements. Therefore, in the event there is a loss to the passenger in the form of a crime, accident and loss/damage to luggage, the public demands clear legal protection. Cases of online-transportation driver accidents that result in injury or death of passengers can also occur, (https://sumselupdate.com/ kecelakaan-di-jalan-demang-palembang-pengemudi-dan-penumpang-ojek-onlinemengalami-luka-luka/, accessed on 30 June 2019) likewise the loss of passenger goods due to the negligence of the driver or human error (https://www.tribunnews.com/ regional/2019/06/28/driver-ojek-online-terpental ditabrak-mobil-xpander-dompetpenumpang-hilang-begini-kondisinya, accessed on 15 July 2019). Such conditions only leave a relationship between the passenger and the driver, while the provider of the application platform remains free of sanctions. (https://www.merdeka.com/ peristiwa/kecelakaan-hingga-penumpang-luka-driver-ojek online-divonis-dua-bulan10-hari.html, accessed on 28 July 2019). Based on the foregoing discussion, the author will discuss legal protection against losses incurred by passengers in online transportation mode.

\section{RESEARCH METHODS}

This type of research is normative legal research in prescriptive. This research is intended to examine the coherence between legal norms and legal principles, between Law and legal norms, as well as the coherence between individual behavior and legal norms (Peter Mahmud Marzuki, 2014: 41-42). Whereas the approach used is the Statute Approach and Conceptual Approach (Peter Mahmud Marzuki, 2014: 136). The legal materials that used are primary legal material, namely the Civil Code, Law Number 22 of 2009 on The Road Traffic and Transport (hereinafter abbreviated to LLAJ Law/ Undang-Undang Lalu Lintas dan Angkutan Jalan ), Law Number 8 of 1999 on The Consumer Protection (hereinafter abbreviated to UUPK Law/ Undang-Undang Perlindungan Konsumen), Financial Services Authority Regulations Number: 1/Pojk.07/2013 on The Consumer Protection in the Financial Services Sector (POJK PKSJK), Law Number 11 of 2008 on The Information and Electronic Transactions jo. Law Number 19 of 2016 on The Amendments to Law Number 11 of 2008 on Electronic Information and Transactions and Law Number 13 of 2003 on The Labor (Labor Law). While the secondary legal materials are in the form of scientific work and other legal research such as scientific articles and journals. All legal materials are collected through library research, legal materials 
are analyzed deductively and presented descriptively by addressing and describing as they are, in accordance with the issue under presented in the research.

\section{RESEARCH RESULTS AND DISCUSSION}

Go-Jek and Grab are trademarks of a technology-based company that provides applications in the form of platforms to bring service users and service providers in the transportation of goods or people. A legal relationship is a relationship between two or more legal subjects. In this legal relationship, the rights and obligations of one party are dealing with the rights and obligations of another party (Soeroso, 2011: 269). There is a triangular relationship between the platform provider (example: Gojek and Grab), the driver and the passenger. Passengers and drivers use applications with different means but complementary to each other. Passengers get services as consumers, while drivers provide services. The relationship between the two is facilitated by the application service provider. While the relationship between the driver and the application service provider is a partnership relationship based on a standard agreement with the application provider which provides a standard contract. Drivers are faced by the choice of take it or leave it, as well as passengers.

Prospective users who will use Go-Jek/Grab must go through an online application which applications for mobile users with iOS and Android operating systems may access (Andika Wijaya, 2016: 1). On the highway, the relationship is dominated by passengers and drivers, while the application service provider (Go$\mathrm{Jek} / \mathrm{Grab}$ ) is only an intermediary tool. Therefore, in the event there is a loss, the causality relationship is more common between the passenger and the driver (Kukuh Tejomurti, 2017: 63-64). If reviewed from the civil aspect, the legal position of online transportation companies can almost be compared to the legal position of a commissioner (intermediary) because the function of online transportation companies (Go-Jek/Grab) in transaction activities is as an intermediary to bring together service providers (transporters) and service users. However in the application, an agreement between an online transportation company (Go-Jek/Grab) and a driver is a partnership agreement with a standard type of agreement that is not an agreement authorizing accompanied by a commission.

Accidents on passengers caused by driver mistakes usually occur because the driver is speeding, exhausted and does not obey traffic signs. Therefore, the accident is a considered Act Against the Law with real losses that have been suffered (material) and the benefits to be gained in the future (Immaterial). So as, if Article 1365 of the Civil Code occurs, "A party who commits an illegal act which causes damage to another party shall be obliged to compensate therefor". Article 1367 paragraph 1 of the Civil Code states that, "An individual shall be responsible for the damage which he has caused by his own act, as well as for that which was caused by the 
acts of the individuals for whom he is responsible, or caused by matters which are under his supervision."

According to Philipus M. Hadjon, legal protection is a collection of regulation or rules that enable protection one thing from another. With regard to consumers, the law provides protection of the customer's rights from something that results in the fulfillment of those rights. Even though the internet is a virtual world, legal protection is still needed to regulate people's actions because, first, people who are in cyberspace are people who are in the real world. The community also has values and interests both individually and collectively which must be protected by law. Second, transactions that occur in cyberspace are also transactions conducted by the public and have an influence in the real world, both economically and non-economically (Qur'ani Dewi Kusumawardani, 2019: 18).

The purpose of law in general, among others, is to create justice, security, order and to enforce the law consistently without discrimination (Abdulkadir Muhammad, 2010: 2). If these goals have not been achieved, it can be interpreted that the existing legislation has not been able to provide legal protection, which in this research will concern the losses suffered by passengers for online transportation modes, both using cars (online cars) and motorbikes (online motorcycle taxi) ). This happened due to the lack of law and regulations described as follows:

\section{A. LLAJ Law}

Article 47 of the $L L A J$ Law regulates the type and function of vehicles. It was used as a determinant of what vehicles are considered to capable in providing security and safety in accordance with the Minimum Service Standard which include: security, safety, comfort, affordability, equality and order (Article 141 of the $L L A J$ Law).

Article 47 of the LLAJ Law states that,

(1) The vehicle shall consist of:

a. motorized Vehicle; and

b. non Motorized Vehicle.

(2) motorized Vehicle as referred to in paragraph (1) letter shall be classified based on the type of:
a. motorcycle;
b. passenger car;
c. bus;
d. cargo car and
e. special vehicle.

(3) motorized Vehicle as referred to in paragraph (2) letter b, letter c, and letter $\mathrm{d}$ shall be classified based on the function of: 
a. private motorized Vehicle; and

b. public motorized Vehicles.

Based on the different functions of the vehicle above, there are differences on the vehicle license plate. The license plate with a yellow color base with black writing color is public transportation. The LLAJ Law does not regulate the use of Private Motorized Vehicles (black plates) because these vehicles fall into the category of private property, and the state does not have the authority regarding the use of private property. Everything involving the use of personal property rights is based on Civil Code and the Criminal Code. The state only regulates everything that concerns the public interest (Ahsani Amalia Anwar, 2017: 235). Go-Car and Grab-Car are classified as special rental transportation as regulated in Article 1 Number 7 of Ministry of Transportation Regulation Number 118 of 2018.

Article 138 paragraph (3) stipulates that "People and/or public transportation can only be made by the Public Motorized Vehicle." The word "only" in the article provide narrow definition of public transportation for people and/or goods which are required to use public motorized vehicles. This results to the online transportation contradiction to provision of Article 47 (3) of the LLAJ Law, which explains that what is meant by Public Motor Vehicles only includes passenger cars, bus cars, and cargo cars. Whereas motorbikes and special vehicles are not included as General Motorized Vehicles. Which makes Timothy K. L. Tobing asserted that motorcycle transportation are not included in public transport contained in the LLAJ Law (Timothy K. L. Tobing, 2017: 123).

Another weakness of the $L L A J$ Law relates to the partnership relationship between drivers and application companies as Article 15 of the Minister of Transportation Regulation Number 12 of 2019 on The Safety Protection of Motorcycle Users for Public Interest Application company statuses such as Go-Jek (Aplikasi Karya Anak Bangsa, Co, Ltd) and Grab (Solusi Transportasi Indonesia, Co, Ltd) are registered with the AHU Directorate General as Electronic System Providers (PSE) or application companies (plattform) not as public transportation companies. Therefore, the LLAJ Law does not have authority over the application company in the event of a loss to the passenger because the responsibility is limited to the implementation of the application (Kukuh Tejomurti, 2017: 114). Even though the driver is the person who directly carries out and is responsible for the person and/or the goods he is transporting, but in the recruitment process, it is done by the application company rather than the transportation department authority. In that case, the purpose of transportation for law enforcement and legal certainty for the community has not been maximumly reached. 


\section{B. UUPK Law}

To minimize losses arising from e-commerce, the UUPK provides legal certainty by providing clear limits on the rights and obligations of consumers and business actors. Consumer rights and obligations are regulated in Articles 4 and 5 of the $U U P K$, while the rights and obligations of business actors are regulated in Articles 6 and 7 of the UUPK. The fulfillment of the rights and obligations by the parties is guaranteed by the government as a form of fostering the implementation of consumer protection as regulated in Article 29 Paragraph 1 of the UUPK.

Due care theory explains that consumers and producers are in a position not aligned/balanced because the company has knowledge and expertise that is not owned by consumers so the company has strong and profitable position (Zulham, 2013: 65-80). In addition, the ease of offering and accepting of a product which sold through e-commerce makes unscrupulous persons using this e-commerce facility in trading their products which do not meet the requirements for trading in Indonesia (Deky Priadi, 2018: 660). This may occur because of the lack of clarity in the existing rules that make the driver's position weak when dealing with companies such as Gojek and Grab (Luthvi Febryka Nola, 2018: 1).

Ordering online transportation services such as Grab and Go-Jek through the electronic agreement is conducted by a clickwrap agreement, in which the consumer must agree to the conditions stated in the contract by clicking on the sign of agreement before completing the transaction (Paustinus Siburian, 2004: 66-68). Problems occur when consumers have a low level of awareness and understanding of their rights, this correlates with the consumer's education. Indonesian consumers in terms of e-commerce tend to agree without reading and understand the contents of the terms and conditions that contain standard clauses because they feel they have obtained the goods and/or services they need. Therefore the company is obliged to guarantee the interests of consumers so as not to be harmed.

When referring to the partnership contract between the Go-Jek company, which is a merger of Paket Global Semesta, Co, Ltd., Aplikasi Karya Anak Bangsa, Co, Ltd and Dompet Anak Bangsa, Co, Ltd and Driver (partners) there are clauses related to the relinquishment of responsibility which reads:

"Partners hereby acquit PGS (Go-Jek company) from all kinds of claims, lawsuits, or other legal actions, both in a civil lawsuit and any criminal lawsuits experienced by the Partner, in any form related to the services offered, provided, held or completed by the Partner through the Application through a partnership under this Agreement." 
Based on this clause, Paket Global Semesta, Co, Ltd (Go-Jek company) relinquishes all responsibility caused by the driver (partner). If reviewed from the $U U P K$, the legal position of the driver of Go-Jek is not as a consumer (because the relationship is a partnership). Whereas the position of Paket Global Semesta, Co, Ltd as a business actor relinquishes itself from the obligation of compensation claims by the transportion service user. New regulation governing the legal position of application provider companies (platforms), partners (transporters), as well as application service users in traffic protection laws for consumers to limit contracts that are arranged based on the principle of freedom of contract is needed.

A standard contract is an agreement that bound the parties that sign it, although there are many transfers of liability from the contract designer to the recipient of the contract. However, any losses that arise in the future will still be borne by parties who must be held accountable based on the clause of the agreement, except if the clause is contrary to the prohibited clause under Article 18 of the UUPK, among others (Ahmadi Miru, 2016: 45):

a. Transfer of responsibility;

b. Regulates the verification of the benefits loss of services purchased by consumers;

c. Gives the right to businesses actor to reduce the benefits of services or consumer property;

d. States consumers are subject to new rules;

e. Placing a standard clause that is difficult to see;

These restrictions indicate the government's seriousness to protect consumers from ignorance and powerlessness in obtaining goods and/or services through standard clauses.

$U U P K$ is still weak against e-commerce consumer protection because in e-commerce, if an agreement that contains a standard clause is agreed to, the consumer is bound by a 'contract'. The principle of freedom of contract stipulated in Article 1338 paragraph (1) of the Civil Code explains that, "All legally executed agreements shall bind the individuals who have concluded them by law". The article also contains the principle of pacta sunt servanda which means the agreement is legal for its maker and must be obeyed as a law. But then Article 1338 is limited by the provisions of Article 1339 of the Civil Code, "Agreements shall bind the parties not only to that which is expressly stipulated, but also to that which, pursuant to the nature of the agreements, shall be imposed by propriety, customs, or the law ".

The electronic agreement on Grab and Go-Jek is indeed valid because of the principle of freedom of contract but must pay attention to propriety and existing 
laws. In fact, this electronic agreement violates the UUPK with its exoneration clause which is detrimental to consumers, but the lack of firmness regarding the violation makes this electronic agreement a reference for implementing online transportation mode.

In addition, the UUPK cannot reach businesses outside the national jurisdiction of the Republic of Indonesia. This condition causes the UUPK cannot fully apply to e-commerce transactions carried out by parties domiciled in different legal jurisdictions (Iman Sjahputra, 2010: 2). Fortunately in this case, Go-Jek and Grab are domiciled in Indonesia which makes them bound to the UUPK.

Apart from being a online transportation company, the Go-Jek company is also a fintech company within the scope of fintech payment companies through Go-Pay. Financial Services Authorirty has issued regulations relating to consumer protection in the financial services sector namely the Financial Services Authority Regulation Number: 1/Pojk.07/2013 on The Consumer Protection for the Financial Services Sector. The Financial Services Authority Regulation has not yet regulated the legal position of Fintech as a business actor, because Fintech is not included in any of the businesses types mentioned in Article 1 number 1 of the Financial Services Authority Regulation. The legal implications if Go-Jek is not a legal subject in the UUPK or Financial Services Authority Regulation, then consumers cannot submit liability claims either personally or class action to the Go-Jek company if a loss occurs. Whereas Go-Jek service users are included in the consumer category as stated in article 1 number 2 Financial Services Authority Regulation that Consumer means any person that invests his/her funds and/or uses the benefit of services provided by a Financial Services Institution. Regulations related to Fintech payment has not regulated, but the definition of fintech as a financial service institution can be seen in Article 2 number 1 of the Financial Services Authority Regulation Number 77/Pojk.01/2016 on The Information Technology-Based Money Lending and Borrowing Services which states that the Fintech Peer to Peer Landing Provider stated as Other Financial Services Institutions.

Both the UUPK Law and the Financial Services Authority Regulation on The Financial Consumer Protection actually regulate consumer protection in conventional transactions. In case there are still loopholes to occur for things that harm consumers of e-commerce, especially in terms of supervision. According to Deky Priadi (2018: 658), the implementation of e-commerce transactions must be balanced with the existence of strict supervision in every implementation.

Supervision (Article 30 of the Company Law) is more heavily borne by the role of the community and the Non-Governmental Consumer Protection 
Institute ( $L P K S M$ ) compared to the role of the government which is carried out by the relevant minister and/or technical minister. Then Article 30 paragraph (4) of the UUPK above explains the passivity of the government in terms of direct supervision because the government relies on the existence of community reports and/or $L P K S M$ to then take action.

\section{Labor Law}

Many people assume that online drivers have a working relationship with the application provider company. The reasons are vary, ranging from the selection of joining as a driver which is similiar to the selection of prospective employees, the requirement of the driver to 'pledge' certain certficate such as Diploma Certificate until the issue of "wages" or insurance for the drivers. Employement relations are legal relationships that occur between employers and work recipients. The employement relations may occur due to running a job and/or running a company (Abdul R. Saliman 2015: 84-86). In Article 50 of the Labor Law stipulated that Employment relation exists because of the existence of a work agreement between the entrepreneur and the worker/ labourer. According to Article 1 Number 14 of the Labor Law, an (individual) work agreement shall be defined as an agreement made between a worker/ labourer and an entrepreneur or an employer. Further, according to Article 1 Number 15 of the Labor Law The factors that determine the existence of an employment relationship are the job that the worker has to do, the worker's wage, orders and instructions.

This work agreement does not create employment, outsourcing or agency relations between each of them. Partners have the same position in partnership theory unlike subordinates with superiors or workers with employers. However, in reality, the relationship is not an employment relation but a partnership relation. The application provider refuses to mention that certain amount of money given to the driver as wage, but only partnership services which based on a partnership agreement. The implication of the legal relationship that arises between service providers and online drivers from the Perspective of the Labor Law is that no employment agreement arises in a partnership relation. Whereas, the real subordination relationship does exist. Such issues are difficult to disprove in terms of labor law, due to weak regulation. The Labor Law has in fact defined employment relations as relations between employers and workers/laborers based on work agreements, which have the elements of work, wages, and orders. But the Elucidation section of the Labor Law does not explain further and in detail the elements of the relation. So that the harshest interpretation is the most correct one. The Labor Law is weak in regulating online transportation mode due to the strictly relation between the Application Provider Company and the Driver 
which categorized partnership relation (Article 15 of Transportation Ministry Regulation Number 12 of 2019).

\section{The Electronic Information and Transaction Law}

Providers of online application-based public transportation are electronic system providers as a liaison between drivers and service users, which are also the main part of the online application-based public transportation, as the key role in the success of the systems. The clickwrap agreement system on applications such as GoJek and Grab in their services has fulfilled and has applied the theory of supply and demand as the basis for the momentum agreement establishment, as stipulated in Article 20 of the Electronic Information and Transaction Law. The ITE Law has been sufficent in the performing the application of electronic transactions conduct. However, the Electronic Information and Transaction Law has not provided details regarding the legal relations arising from online transportation to passengers with all possible losses.

\section{CLOSING}

\section{A. Conclusion}

Legal protection for the losses incurred by passengers in online transportation mode is considered poor due to weak and lack of regulations such as:

1. LLAJ Law

1) Article 47 (3) of $L L A J$ Law, implicitly concludes that motorbikes are not public motor vehicles, even though Transportation Ministry Regulation Number 12 of 2019 has existed but the provisions only cover the technical implementation;

2) Driver verification is carried out by application company instead of the government (transportation agency);

3) Application companies are not public transportation companies make their responsibilities are limited to the Electronic System Provider rather than the transportation;

2. UUPK

1) UUPK only applies in Indonesia and still regulates e-commerce commerce in detail;

2) Lack of fosterization and supervision (Article 30 of the UUPK) on the implementation of consumer protection, especially in the standard (electronic) agreement with its exoneration clause;

$230 \quad$ Yustisia Volume 8 Number 2 (May-August 2019) Legal Protection For The Loss Of ... 
3. Labor Law

This Law is unable to protect passengers in online transportation modes because the legal relationship between the company and the driver is based on a partnership agreement rather than an employment agreement;

4. The Electronic Information and Transaction Law

This law is weak in protecting passengers in online modes of transportation because the Electronic Information and Transaction Law only protects against the implementation of applications not on the transportation services organized;

\section{B. Suggestions}

The following suggestions can be given:

1. Ministry of Transportation to immediately provide legal certainty, especially for online motorcycle transportation services to remove the conflict with the Law above, such as the LLAJ Law and upgrading the existing public transport system to be able to develop into digital industrial systems to satisfy the needs of the people and encourage economic growth;

2. Application companies shall improve the quality of electronic systems implementation and increase the accuracy of the verification system in the driver recruitment process;

3. Online drivers should continue to improve Minimum Service Standards (SPM) to achieve the purpose of safe transportation;

4. Users of online transportation mode services shall well-understood the contents of the provisions and services as well as verify the suitability of the driver's identity and the type of online transportation mode which has picked listed on the applicaion;

\section{BIBLIOGRAPHY:}

\section{Books:}

Marzuki, Peter Mahmud. (2014). Legal Research (Penelitian Hukum). Jakarta: Prenada Media Group.

Miru, Ahmadi. (2016). Contract Law and Contract Drafting (Hukum Kontrak dan Perancangan Kontrak). Jakarta: Rajawali Pers.

Muhammad, Abdulkadir. (2010). Indonesian Civil Law (Hukum Perdata Indonesia). Bandung: Citra Aditya Bakti.

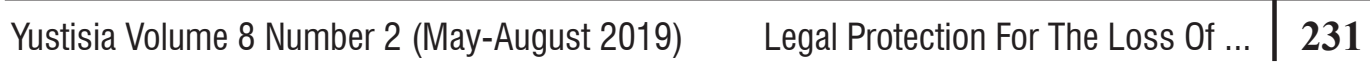


Saliman, Abdul R.. (2015). Bussiness Law for Companies: Theory and Example (Hukum Bisnis Untuk Perusahaan :Teori dan Contoh). Jakarta: Prenadamedia Group.

Siburian, Paustinus. (2004). Online Arbitration: Online Alternative Dispute Settlement (Arbitrase Daring: Alternatif Penyelesaian Sengketa secara Elektronik). Jakarta: Djambatan.

Sjahputra, Iman. (2010). Consumer Protection on The Electronic Transaction (Perlindungan Konsumen Dalam Transaksi Elektronik). Bandung: Alumni.

Soeroso, R. (2011). Introduction to Law (Pengantar Ilmu Hukum). Jakarta: Sinar Grafika.

Wijaya, Andika. (2016). Legal Aspects of The Online Road Transportation Bussiness (Aspek Hukum bisnis transportasi jalan online). Jakarta : Sinar Grafika

Zulham. (2013). Consumer Protection Law (Hukum Perlindungan Konsumen). Jakarta: Kencana Prenada Media Group.

\section{Journals:}

Ahsani Amalia Anwar. (2017). Online vs Konvensional: Keunggulan dan Konflik Antar Moda Transportasi di Kota Makassar. Etnosia: Jurnal Etnografi Indonesia, Volume 2, Number 2, Dessember 2017.

Deky Priadi. (2018). Pengawasan E Commerce Dalam Undang-Undang Perdagangan Dan Undang-Undang Perlindungan Konsumen. Jurnal Hukum \& Pembangunan . $48^{\text {rd }}$, Number 3, July-September 2018.

Endang Wahyusetyawati. (2017). Dilema Pengaturan Transportasi Online. Jurnal RechtsVinding. ISSN 2089-9009, Mei, 2017.

Kukuh Tejomurti. (2017). The Personal Electronic Data Security on The Implementation of Solo Smart City According to The Perspective of Privacy Protection Law, Journal of Law, Policy, and Globalization, Volume 66 (2017). See: https//iiste.org./journals/index.php/JLPG/issue/view/3228

Kukuh Tejomurti, et. al., (2018) Legal Protection for Urban Online-Transportation User's Personal Data Disclosure in the Age of Digital technology, Padjadjaran Journal of Law, Volume 5, Number 3, 2018

Kukuh Tejomurti. (2017). Right to Safety and Security for Passengers Traveling By The Public Road Transportation. Yustisia Jurnal Hukum, Volume 6, Number 1

Luthvi Febryka Nola. (2018). Perjanjian Kemitraan Vs Perjanjian Kerja Bagi Pengemudi Ojek Online. Bidang Hukum Info Singkat: Kajian Singkat Terhadap Isu Aktual Dan Strategis. Volume 10, Number 7, April 2018.

P. Ashokkumar. (2018). E-Commerce law and its legal Aspects. International Journal of Law. Volume 4, Issue 1, January 2018.

232 Yustisia Volume 8 Number 2 (May-August 2019) Legal Protection For The Loss Of ... 
Qur'ani Dewi Kusumawardani. (2019). Perlindungan Hukum Bagi Pengguna Internet Terhadap Konten Web Umpan Klik Di Media Online. Jurnal Penelitian Hukum De Jure. Volume 19, Number 1, Maret 2019.

Timothy K. L. Tobing. (2017). Perlindungan Hukum Terhadap Konsumen Transportasi Berbasis Aplikasi Menurut Undang-Undang Nomor 11 Tahun 2008. Lex Crimen. Volume 6, Number 5, Juli 2017.

\section{Websites:}

https://www.gojek.com/app/kilat-contract/, accessed on 30 June 2019

https://sumselupdate.com/kecelakaan-di-jalan-demang-palembang-pengemudi-danpenumpang-ojek-online-mengalami-luka-luka/, accessed on 15 July 2019

https://www.merdeka.com/peristiwa/kecelakaan-hingga-penumpang-luka-driverojek-online-divonis-dua-bulan-10-hari.html, accessed on 20 July 2019. 